\title{
THE LITHOLOGICAL PECULIARITIES OF THE RED TERRIGENOUS (KARTAMUSH) FORMATION (THE SOUTH-EASTERN PART OF THE DNIEPER-DONETS DEPRESSION)
}

\section{S.B. Shekhunova ${ }^{1}$, A.A Shevchenko², S.A. Matchoulina'}

\author{
ЛІТОЛОГІЧНІ ОСОБЛИВОСТІ ПОРІД ТЕРИГЕННОЇ ЧЕРВОНОКОЛІРНОЇ \\ (КАРТАМИШСЬКОЇ) ФОРМАЦІї (ПІВДЕННО-СХІДНА ЧАСТИНА \\ ДНІПРОВСЬКО-ДОНЕЦЬКОЇ ЗАПАДИНИ) \\ С.Б. Шехунова', О.А. Шевченко², С.О. Мачуліна'
}

\begin{abstract}
The red terrigenous (kartamush) formation in the south-eastern part of the Dnieper-Donets Depression (Kobzev structure) is investigated. It is characterized by high thickness (up to $350 \mathrm{~m}$ ), stratification rhythmicity, and the absence of carbonate and sulphate rocks. The lithologic peculiarities of formations rock and their epigenetic alteration have been studied. It is determined that formation deposition took place in shallow-water basin of high level salinity without any features of active hydrodynamic nearby the coastline in subplatform condition with arid climate. The area of material supplying was peneplaine.

Key words: red terrigenous (kartamush) formation, epigenetic alteration
\end{abstract}

Досліджено теригенну червоноколірну (картамишську) формацію у південно-східній частині Дніпровсько-Донецької западини (Кобзівська структура). Ії̈ будова відрізняється значною потужністю (до 350 м), ритмічністю, відсутністю потужних прошарків карбонатних та/або сульфатних порід. Вивчено літологічні особливості порід формації та їх вторинні зміни. За результатами досліджень визначено, що накопичення речовини формації відбувалося у мілководному басейні підвищеної солоності без ознак активного гідродинамічного режиму поблизу берегової лінії за субплатформених умов в арідному кліматі, областю живлення якого була пенепленізована рівнина.

Ключові слова: теригенна червоноколірна (картамишська) формація, епігенетичні зміни

\section{ВСТУП}

Пізньокарбонові-ранньопермські відклади південно-східної частини Дніпровсько-Донецької западини (ДДЗ) формувались в умовах порушення синхронності тектонічних подій території ДдЗ та Донбасу: територія Донбасу піднімалася та зазнавала складкоутворення, а ддЗ продовжувала занурюватись. Утворилися низка котловин та такі депресії (з південного сходу на північний захід): Бахмутська улоговина, Орчиківська, Кошелево-Срібненська депресії та Свободський прогин. Тут сформувалися теригенна червоноколірна (картамишська), соленосна (микитівсько-слов'янсько-краматорська, 3 калієносною краматорською субформацією) та моласоїдна (дронівська) формації. Потужність нижньопермських відкладів ДДЗ змінюється від 2500-2700 м у депресіях її південно-східної частини до повного ї виклинювання на найбільш піднятих частинах западини $[1,5]$. Дослідженнями М.П. Кожич-Зеленко, Ф.Ю. Лапчик, Г.Д. Кіреєвої, І.Ю. Лапкіна, Р.М. Пістрак, В.І. Андрєєвої, П.Д.Потієвської, В.К. Іванова, В.Д. Когана, Я.І. Коломієць, К.С. Супрунюка, Л.П. Нестеренка, В.Л. Литвинова, І.В. Галицького, Л.Б. Чутко, М.С. Шмекера, Л.С. Макарова, Л.Я. Сайдаківського, О.Ю. Лукіна, С.М. Коренєвського, В.П. Боброва, Д.П. Хрущева та інших фахівців [1-5] виявлені основні літостратиграфічні підрозділи формації, які скорельовані з основними підрозділами Донбасу, встановлена ритмічність будови нижньопермських відкладів, описані основні типи порід. Відкриття нових родовищ вуглеводнів у відкладах верхнього карбону і нижньої пермі та необхідність оцінки перспективності соленосних утворень на корисні копалини диктують потребу у більш детальних дослідженнях цієї частини розрізу.

Як відомо, проблема границі карбону-пермі - одна з найдискусійніших у стратиграфії палеозою ДДЗ. Формування картамишської формації (принаймні її нижньої частини) відбувалося саме у цей час. Не обговорюючи проблеми границі вцілому, зазначимо, що теригенна червоноколірна (картамишська) формація розглядається нами у такому об'ємі: її нижня границя визначається за зникненням у розрізі алювіальних пісковиків верхнього карбону (відповідає підошві карбонатного горизонту $Q_{1}$ ), верхня - за появою у розрізі ангідритів, кам'яної солі (відповідає підошві карбонатного горизонту $Q_{8}$ ) або у разі випадіння частини розрізу - за трансгресивним передмикитівським неузгодженням.

Формація складена теригенними утвореннями піщано-глинистого складу - аргілітами, аргілітоподібними глинами, пісковиками та алевролітами з підпорядкованими шарами теригенно-карбонат- 
них та теригенно-сульфатних порід; утвореннями континентальних, перехідних та морських фацій; має форму ускладненої лінзи. На теригенній червоноколірній (картамишській) формації з трансгресивним неузгодженням залягає соленосна. Однією з площ, де теригенні червоноколірні утворення потребують на детальне вивчення, $є$ Кобзівська.

На Кобзівський площі пермські відклади розкриті багатьма свердловинами, в яких їх товщина сягає 1620 м, що значно перевищує потужність останніх на Дробишівській площі (1370-1410 м), Волохівській - до 1000 м, Балаклейсько-Савинській (910-986 м), Балаклейській - 985 м, Таранушинській - 810 м, Морозівській - 910-980 м. Кобзівське підняття належить до Кобзівсько-Червонопавлівсько-Мечебилівського антиклінального валу, який розділяє центральний грабен ддЗ та ії південну прибортову зону. Структурно-тектонічна будова цієї частини западини характеризується розташуванням соляних валів, ускладнених позитивними та негативними плікативними формами. Однією з позитивних форм і є Кобзівська брахіантикліналь субширотного простягання, яка має розміри $13 \times 6$ км та вертикальну амплітуду понад 250 м (по відбиваючому сейсмічному горизонту, який зіставляється з башкирським ярусом середнього карбону). Керном відклади червоноколірної формації охарактеризовані слабо. Тому при розчленуванні широко застосовуються результати інтерпретації геофізичних досліджень свердловин.

Мета даної статті - охарактеризувати відклади червоноколірної теригенної (картамишської) формації на Кобзівській площі, які є перспективними на пошуки вуглеводнів. Структурно-текстурні особливості будови порід та їх речовинний склад значною мірою визначають такі характеристики порід, як пористість, проникність та насиченість пластовими флюїдами. Тому акцент поставлено на визначення літологічних особливостей порід формації.

\section{МАТЕРІАЛ ТА МЕТОДИ ДОСЛІДЖЕНЬ}

В основу статті покладено результати вивчення керну та інтерпретації геофізичних досліджень свердловин Кобзівської та прилеглих площ, що розкрили нижньопермські відклади. Комплекс досліджень включає макроскопічний опис керна, петрографічні, електронномікроскопічні, рентгенівські методи. Елементний склад мінеральних утворень визначався із застосуванням енергодисперсійного рентгенівського аналізатора (макрокомпоненти) та спектральним аналізом (мікрокомпоненти).

Склад порід для зручності зіставлення визначався у відсотках: вміст цементу та уламків. Далі визначався мінеральний склад уламкової частини та цементу, кожний з яких приймався за $100 \%$. Нижньопермські відклади дДЗ - ідеальний об'єкт для застосування літостратиграфічних методів для іх розчленування, а комплексні літологічні дослідження та стадіальний аналіз - ефективний метод вивчення теригенних утворень. Оцінювався ступінь вторинних епігенетичних змін порід як основа для подальших узагальнень.

\section{ОТРИМАНІ РЕЗУЛЬТАТИ}

На рис. 1 представлено зведений розріз теригенної червоноколірної (картамишської) формації Кобзівської структури. Відклади мають товщини до 360 м, наприклад, у свердловина Кобзівська-52 формацію виділено в ін. 3312-3673 м. На Кобзівській структурі формація представлена ритмічним перешаруванням пісковиків, алевролітів, аргілітів та аргілітоподібних глин різних відтінків вишневобурого та сірого кольорів. Сіроколірні утворення становлять не більше 10\% порід розрізу (сіроколірний аргіліт піднято з гл.3434-3442, а зеленувато-сірі алеврито-пісковики - 3 гл. 3469-3477м (рис. 1, зр. 5, 10).

За даними ГДС та досліджень керна в розрізі теригенної червоноколірної (картамишської) формації виділяється чотири літогеофізичні товщі (знизу вверх): переважно глиниста (інт.3705-3607 м) і в основному піщана інт. 3607-3553 м в св. Кобзівська-52; переважно глиниста (інт. 3553-3439 м) і здебільшого піщана (3439-3312 м) у св. Кобзівська-50 (рис. 1). Ці чотири товщі чергуються в розрізі, тому можна об'єднати їх у два глинисто-піщані макроритми осадонакопичення (перший - інт. 37053553 м, другий - інт. 3553-3312 м). Піщані товщі цих ритмів складені дрібнозернистими пісковиками алевритистими й алевролітами, а глинисті вміщують тонкі прошарки алевролітів. В основі піщаних товщ залягають реперні газонасичені (Кнг = 0,83-0,65-0,55\%) пісковики з пористістю 11-14\% в свердловині Кобзівська-50 і 16-18\% у свердловині Кобзівська-52. В зазначених вище двох макроритмах виділяються піщано-глинисті ритми менших порядків (рангів). Врахування їх літологічного складу і по- 


\section{С.Б. ШЕХУНОВА, О.А. ШЕВЧЕНКО, С.О. МАЧУЛІНА}

рядку залягання у розрізі дозволяє більш впевнено корелювати розрізи свердловин за матеріалами ГДС. Крім того, порушення порядку залягання піщано-глинистих ритмів або відсутність деяких з них чи якої-небудь частини ритму (піщаної або глинистої) може свідчити про наявність переривів осадконакопичення та/або розмиву. Так, у розрізі картамишської світи Кобзівської площі можливий перерив у підошві меліхівської світи, оскільки вона починається не з базального пісковику, а з відносно потужного (5 м) глинистого пласта з тонкими прошарками у верхній частині карбонатного алевроліту, порушуючи у такий спосіб закономірну ритмічність (піщаник-глина); седиментаційний перерив також може спостерігатися в покрівлі меліхівської світи. Зіставлення розрізів меліхівської світи та картамишської формації в цілому з іншими одновіковими розрізами центральної (свердловина Срібненьська-309) і південно-східної частин Дд3 (свердловина Орчиківська-410) дозволяє зробити припущення про існування перерв в підошві і покрівлі меліховської світи.

Комплексні літологічні дослідження зразків досліджуваної формації показали, що найхарактернішою текстурою порід $є$ горизонтальна (смугаста) шаруватість у дрібнозернистих пісковиках і алевролітах та хвиляста (з елементами косохвилястої), лінзоподібна - в алевролітах та плямиста - в аргілітах. Шаруватість обумовлена незначною зміною гранулометричного та мінерального складу шарів (зокрема, пошаровими скупченнями слюди, органічних решток, пігментуючих мінеральних форм), що може проявлятися і в різному забарвленні - появі більш темних або світлих прошарків. Плямиста текстура зумовлена нерівномірністю забарвлення порід та присутністю світліших (освітлених) ділянок карбонатного оглеєння. За речовинним складом та структурно-текстурними особливостями будови виділено сім різновидів порід:

1. Червоноколірні пісковики (рис. 1, зр. 1) дрібнозернисті алевритисті горизонтально-шаруваті.

2. Червоноколірні строкаті пісковики (рис. 1, зр. 3, 9) дрібнозернисті алевритисті з неритмічною горизонтальною шаруватістю та накладеними плямами карбонатного оглеєння засолонені (містять до 3\% галіту).

3. Червоноколірні пісковики (рис. 1, зр. 4) дрібнозернисті алевритисті з прошарком змінної товщини внутрішньоформаційного перемиву та міліметровими невитриманими прошарками бариту.

4. Червоноколірні алеврито-пісковики (рис. 1, зр. 6, 7, 11) засолонені (містять до 3\% галіту).

5. Червоноколірні та строкаті аргіліти горизонтально- та хвилястошаруваті з елементами седиментаційного брекчіювання прошарків, засолонені (рис. 1, зр. 2);

6. Зеленувато-сірі алеврито-пісковики з шарами косохвилястої шаруватості, карбонатні (рис. 1, 3p. 10);

7. Сіроколірні щільні аргіліти з елементами сланцюватості, тонковідмучені, з численними рослинними рештками (рис1, зр. 5).

3 метою встановлення характерних ознак порід, які можливо використати для кореляції розрізів та виявлення стадій перетворення порід, наведено короткий опис основних типів порід.

1. Червоноколірні пісковики (зр. 1) дрібнозернисті алевритисті горизонтально-шаруваті. Пісковик дрібнозернистий червоноколірний хлорит-іліт-кварцовий з іліт-карбонатним цементом; каолініт розподілений у породі нерівномірно. Текстура неясно виражена тонко- (товщина невитриманих шарів - до 1,0 мм), горизонтально-паралельно-шарувата; порода забарвлена у вишнево-бурий колір. Структура алеврито-дрібнопсамітова (дрібнозерниста). Мікротекстура орієнтована, зумовлена пошаровим розташуванням лусок мусковіту, пасм гідромусковіту, іліту, дрібних рослинних решток та гідроксидів заліза. Цемент становить до 10\%. Цемент контактово-поровий, на окремих ділянках плівковий алеврито-пелітовий; представлений гідроксидами заліза, ілітом, хлоритом, просякнутий карбонатом. Уламкова частина породи представлена кварцом - до $65 \%$, польовими шпатами - 15\%; ілітом - $5 \%$; хлоритом - до 5 \%, каолінітом - до 5 \%, слюдою (мусковіт) - до 5 \%; кислими плагіоклазами - до 2 \%; акцесорні мінерали - циркон, монацит, апатит. Більшість мінералів, що складає уламкову частину породи, кородовані, змінені. В породі встановлено бітумоїди (до 2\%).

2. Червоноколірні строкаті пісковики (зр. 3, 9) дрібнозернисті алевритисті з неритмічною горизонтальною шаруватістю та накладеними плямами карбонатного оглеєння засолонені. Пісковик дрібнозернистий алевритистий червоноколірний хлорит-іліт-кварцовий. Текстура неясно виражена тонко- (товщина невитриманих прошарків до 1,5 мм) горизонтальношарувата, в окремих прошарках порушена взмучуванням (?) та присутністю одиничних уламків дрібної аргілітової гальки; порода за- 
барвлена у вишнево-бурий колір, забарвлення неоднорідне, зумовлене присутністю лінзоподібних ділянок карбонатного накладеного оглеєння у породі, забарвленій гідроксидами заліза. Ділянки оглеєння складають до 30\%. Структура алеврито-дрібнопсамітова (дрібнозерниста). Мікротекстура орієнтована, зумовлена пошаровим розташуванням лусок слюди. Цемент сягає до 20\%. Цемент контактово-поровий, на окремих ділянках плівковий алеврито-пелітовий; представлений гідроксидами заліза, ілітом, карбонатами, ангідритом, в окремих прошарках переважає інкорпораційний цемент. В межах лінзочок оглеєння (розмір 3×1,5мм) цемент чистий, карбонатний (доломітовий) базальний, спаритовий. Порода містить до 3 \% галіту, який утворює міліметрові лінзоподібні прошарки. Уламкова частина породи представлена кварцом - до 50 \%, ілітом - до 15\%, хлоритом - до 15\%, каолінітом - до 10 \%, гідрослюдою - до 5\%, слюдою (мусковіт) - до 3 \%; кислими плагіоклазами - до 2 \%; акцесорними мінералами - циркон, монацит. Більшість мінералів, що складають уламкову частину породи кородовані, змінені. В породі встановленро бітумоїди (до 2\%); вона має слабий запах вуглеводнів.

3. Червоноколірний пісковик (зр. 4) дрібнозернистий алевритистий без шаруватості; складений хлоритом (до 20\%), ілітом (до 30\%), кварцом (до 50\%), гідроксидами заліза, каолінітом у різних співвідношеннях та містить прошарки змінної товщини (від 10 до 30 мм) внутріформаційного перемиву; цемент іліт-гідрослюдистий, контактово-поровий, структура на багатьох ділянках механоконформнозерниста (до 40\% зерен цементуються без цементу внаслідок інкорпорації одних зерен в інші). Прошарки - утворення внутріформаційного перемиву, складені дрібногравійним алевритоаргілітом гідрослюдисто-кварцовим, що містить екзотичні включення середньогравійної розмірності. Уламки представлені тонкошаруватим сортованим гідрослюдисто-кварц-карбонатним алевролітом. В породі встановлено міліметрові прошарки бариту (рис. 2, и).

4. Алеврито-пісковик (зр. 6, 7, 11) червоноколірний іліт-хлорит-кварцовий, слабо засолонений (містить до 3\% галіту). Текстура неясно виражена тонко- (товщина невитриманих прошарків до 1,0 мм) горизонтально (паралельно) шарувата та/або хвиляста, в окремих прошарках порушена присутністю одиничних уламків дрібної аргілітової гальки (до 6 мм у діаметрі); порода забарвлена гідроксидами заліза у вишнево-бурий колір, забарвлення неоднорідне, зумовлене присутністю лінзоподібних ділянок освітленої сірої породи (до 20\%) та мікроскупчень галіту. Текстура зумовлена орієнтованим розташуванням в окремих прошарках лусок мусковіту та фенгіту (?) залізо-калій-магнійвміщуючої слюди (можливо, біотит, але не проявляє значного плеохроізму), що мають розмір до 0,4 мм у діаметрі, та присутністю міліметрових хлорит-кварцових прошарків. Структура алеврито-дрібнопсамітова (дрібнозерниста) до алевропелітової. Мікротекстура неоднорідна: орієнтована, зумовлена пошаровим розташуванням лусок мусковіту, пасм іліту, гідроксидів заліза, рідкісних вкраплеників бітумоїдів. Цемент ілітхлоритовий з гідроксидами заліза; розподіляється у породі нерівномірно як між прошарками, так і в межах окремих прошарків (у прошарках становить від 10 до 30\%). Порода має слабий запах вуглеводнів. По біотиту (?) розвиваються мінерали титану (вміст титану змінюється від 6 до 27 ат.\%). У розрізі від піщаних до глинистих порід спостерігається збільшення вмісту титану, який вивільняється при руйнуванні уламкових зерен алюмосилікатних мінералів та накопичується у вигляді вільних оксидів у тонкій фракції цементу пісковиків, алевролітів, аргілітів (рис. 2, є, ж).

5. Червоноколірні та строкаті аргіліти горизонтально- та хвилястошаруваті з елементами седиментаційного брекчіювання прошарків, засолонені (рис. 1, зр. 2); текстура - шарувата та неясношарувата. Аргіліт складений дисперснотонколускуватим хлорит-ілітовим агрегатом з домішком уламків польового шпату та кварцу. Цемент базальний хлорит-ілітовий, становить до 40\% породи. Прошарки відрізняються ступенем впорядкованості уламкових частинок. Аргіліт містить рідкісні прошарки алевроліту добре сортованого, складеного кварцом (до 30\%), польовими шпатами (до 30\%), каолінітом (до 20\%) з лусками слюди, на окремих ділянках має карбонатний спаритовий цемент. Присутність сірих плям оглеєння зумовлює строкату текстуру породи.

6. Зеленувато-сірий алеврито-пісковик з шарами косохвилястої шаруватості, хлорит-кварцовий з карбонатним цементом. У складі уламкової частини встановлено кварц - до 40\%, хлорит - 20\%, польовий шпат - 15\%, каолініт - 15\%, іліт - 10\%. Цемент становить до 20\%, поровий хлорит-іліт-карбонатний. На окремих інтервалах спостерігається цемент вторинний спаритовий карбонатний порового або порово-базального типу, який кородує уламки кварцу та польових шпатів.

7. Сіроколірний щільний аргіліт з елементами сланцюватості тонковідмучений добре сортований з численними рослинними рештками. Характеризується тонко- та мікрошаруватою текстурою, 

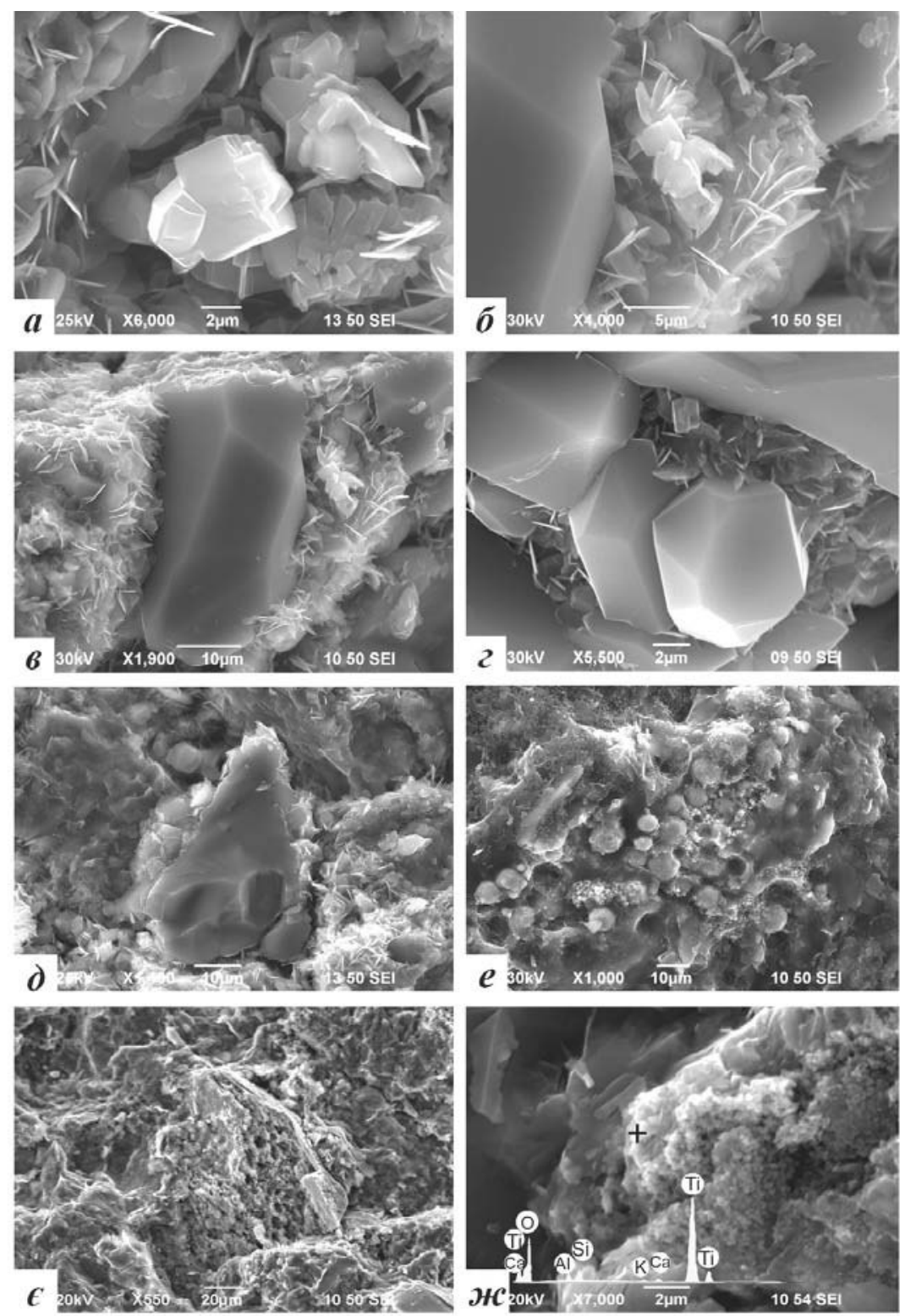

Рис. 2. а-г - епігенетичні новоутворення у поровому просторі пісковиків: аутигенний кварц, іліт, каолініт; д - кутастий уламок кварцу у ілліт-хлоритовому цементі; е - аутигенний діагенетичний дисульфід заліза (переважно пірит), утворює кристалики кубічні, інколи октаедричні та пентагонально-додекаедричні, фрамбоїди (до 0,01 мм в діаметрі) та іхх скупчення; $€$ - зерно ільпиніту; ж - дисперсний $\mathrm{TiO}_{2}$

має плоско-раковистий злом. Породи складені кородованими зернами кварцу (до 10\%), тонко- та дисперснолускуватим хлорит-гідрослюдистим агрегатом, складові якого мають майже однакове оптичне орієнтування. У породі встановлено сполуки міді (у формі хлориду (?), рис. 2, й).

Породи формації зазнали значних вторинних змін. Серед епігенетичних процесів необхідно відмітити хлоритизацію, карбонатизацію, гідрослюдизацію, каолінітизацію, окварцювання. Хлоритизація є одним з найпоширеніших процесів. Хлоритизація проявляється як у цементі, так і розвивається по зернах польових шпатів після гідрослюди. Дуже поширена регенерація кварцу. Спостерігається гідрослюдизація польових шпатів, слюд. Серед діагенетичних новоутворень встановлено пірит, що розвивається по органічних рештках (рис. 2, е). Гідроксиди заліза - первинно-седиментаційного походження; наступні етапи тільки призвели до їх незначного перерозподілу.

\section{ОБГОВОРЕННЯ РЕЗУЛЬТАТІВ}

Аналіз характеру поширення червоноколірної формації у ДДЗ свідчить про значну відмінність типів розрізів. Так, у свердловині Срібненській-309 червоноколірна теригенна формація встановлена на гл. 3080-3318 м. За особливостями літогеофізичної характеристики вона поділяється на три товщі: ритмічну глинисто-піщану (гл. 3207-3080 м); товщини аргілітових шарів - 20-30 м, а більш однорідних піщанистих - до 20 м; грауваково-піщану (гл. 3318-3207 м), представлену крупнозернистими пісковиками з прошарками граувакових пісковиків (34 м), що перекривається 50-метровою тов- 

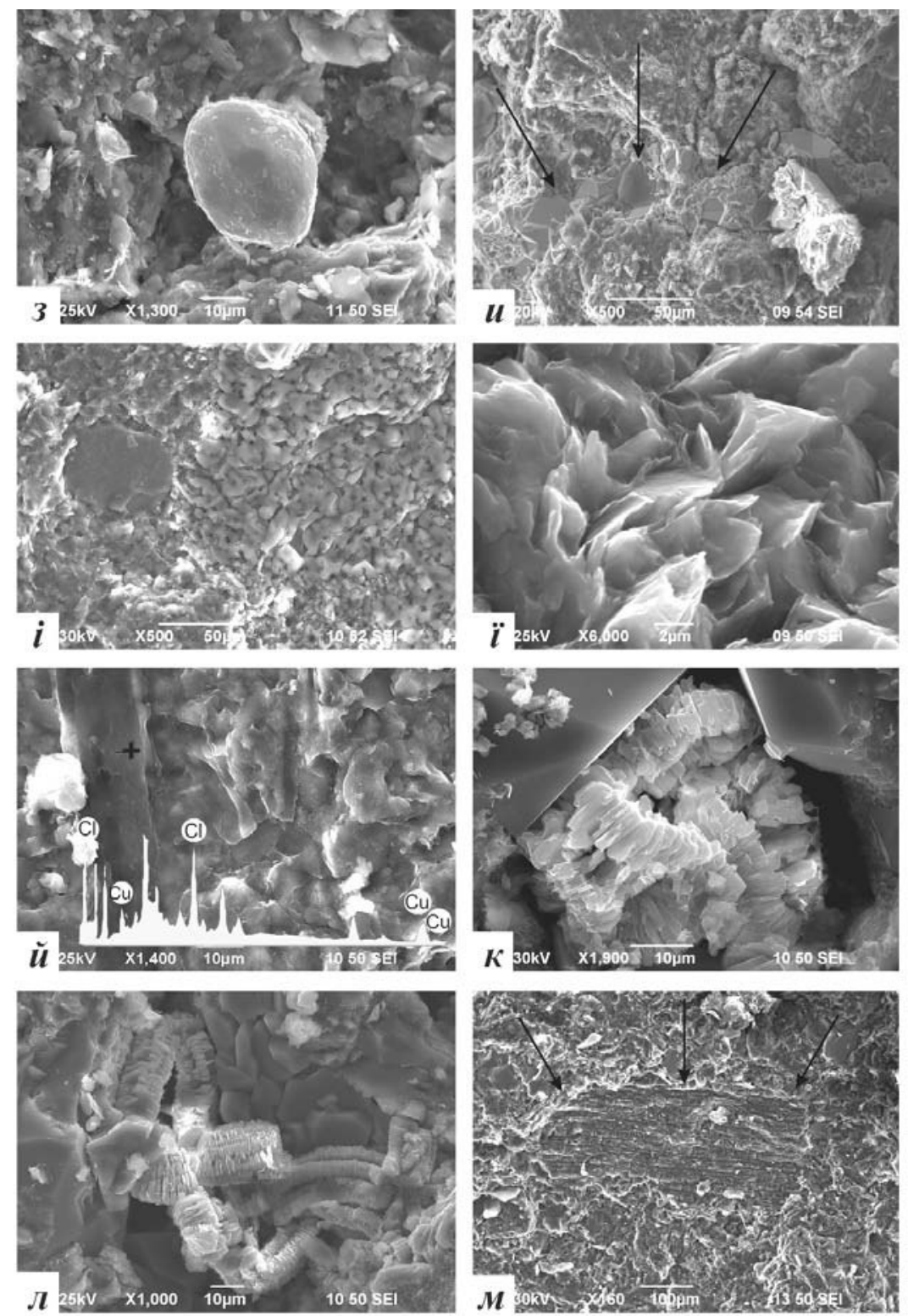

Рис. 2 (продовження). 3 - зерно циркону; и - прошарок бариту; і - будова прошарку галіту; й - сполуки міді (у формі хлориду (?)); к, л - новоутворені текстуровані полікристали каолініту у поровому просторі (рис. 2, к, л); м - рослинні рештки на поверхні окремості сіроколірного алевриту. Електронномікроскопічні знімки виконано в лабораторії фізичних методів досліджень ІГН НАН України. Оператор канд. техн. наук В.В. Пермяков

щею перешарування глинистих пісковиків і алевролітів та 40-метровою товщею граувакових пісковиків з 5-метровим шаром аргілітів у середній частині); алеврито-глинисту (гл. 3318-3400м), складену знизу вверх тонким перешаруванням глин та алевролітів (40 м), строкатими пісковиками (14 м), алевритистими пісковиками (18 м) та алеврито-глинистими породами).

В південній прибортовій частині ДДЗ свердловина Орчиківська-410 розкрила скорочений розріз формації товщиною до 204 м (гл. 1188-1392 м), в якому за геофізичними даними виділяється три товщі. Нижня (гл. 1340-1392 м) - представлена головним чином крупнозернистими пісковиками; середня (гл. 1138-1340 м) - глинисто-алевритова (з малопотужними прошарками пісковиків у нижній частині та переважно глиниста у верхній); верхня (гл. 1138-1188 м) - складена пісковиками. Відклади червоноколірної формації перекриваються аналогами соленосної формації - щільними ангідритами 3 прошарками глинистих карбонатів (гл. 1110-1188 м), які мають показники опору пласта 160 Ом. • м. На Октябрьській площі (св. 4-р, гл. 1890-2018 м) І.В.Галицький [5] виділив строкатоколірний глинистий розріз, в якому формація представлена червоноколірними глинами, що зрідка мають прошарки сірих глин та пісковиків. Т.Ю. Лапчик [5] на підставі аналізу розрізів свердловин на Коломацькій, Колонтаївській, Октябрьській структурах виділено три літологічні пачки: нижню - глинисто-алевролітову, середню - піщано-глинисту та верхню карбонатно-глинисту.

Описаний нами розріз відрізняється значною потужністю, ритмічною будовою, теригенністю потужні прошарки карбонатних та/або сульфатних порід відсутні. Структурно-текстурні дослідження 


\section{С.Б. ШЕХУНОВА, О.А. ШЕВЧЕНКО, С.О. МАЧУЛІНА}

порід показали, що найхарактернішою текстурою порід є горизонтальна (смугаста) шаруватість у дрібнозернистих пісковиках і алевролітах, хвиляста (з елементами косохвилястої) і лінзоподібна у алевролітах та плямиста - аргілітах (аргілітоподібних глинах). Найпоширеніший тип порід - червоноколірні тонкозернисті алеврито-пісковики та аргіліти. Аналогів «сірим зонам», виділеним Л.П. Нестеренком у Кальміус-Торецькій та Бахмутській улоговинах [4] у розрізі поки не встановлено. Породи характеризуються середнім та високим ступенем сортованості. Форма уламкових зерен напівокатана, частина уламків кварцу кутаста (рис. 2, д), проте через епігенетичну змінність порід в деяких зразках визначити первинну окатаність зерен іноді важко. Майже 40\% порід розрізу містять субгоризонтальні мікропрошарки галіту, ангідриту, карбонатів, бариту, мають ділянки з карбонатним та сульфатним цементом (рис. 2, и, і). У складі глинистих мінералів майже не присутній монтморилоніт (встановлено тільки в одній пробі у складі гідрослюдисто-монтморилонітового змішаношаруватого утворення) та розбухаючі змішаношаруваті утворення. Основною їх складовою (за результатами рентгеноструктурного аналізу) є іліт, хлорит (магнезіальний та залізистий) з домішком каолініту. 3 наведеного вище випливає, що накопичення відкладів відбувалося у басейні підвищеної солоності без активного гідродинамічного режиму. Відклади накопичувались у субплатформному режимі в аридному кліматі, областю зносу була пенепленізована рівнина. Про що свідчать, зокрема, і високий ступінь окристалізованості глинистої речовини, відсутність деградованої гідрослюди, підвищений вміст бору та сульфатної сірки. Переважання натрію та магнію у складі поглиненого комплексу свідчать про підвищену солоність басейну в якому формувались осадки (О.Ю. Лукін у [1]).

Розподіл породоутворюючих компонентів визначається механічною та хімічною диференціацією у седиментогенезі, перерозподілом на стадії діа- та катагенезу, а також накладеними процесами. Досліджувані породи характеризуються значним проявом як ката-? так і епігенетичних процесів. Процеси хлоритизації властиві майже всім типам порід. Хлорит утворює різного відтінку зелені лусочки, що плеохроюють, а також дрібнолускуваті агрегати. Найбільш хлоритизований гідрослюдистий цемент порід; спостерігається інтенсивна хлоритизація польових шпатів і кварцу. Хлорит кородує зерна та просякає по мікротріщинах та тріщинах спайності. Окремо треба зупинитись на процесі каолінітизації. Каолініт присутній у відкладах як у вигляді уламкових слабоокатаних зерен каоліну, так і як аутигенний мінерал, що формується у поровому просторі (рис. 2, к, л). Співвідношення та послідовність утворення аутигенних мінералів мають бути уточнені на наступних етапах робіт. Але вже зараз треба зазначити, що необхідно виділити окремий епігенетичний етап каолінітизації порід формації. Мінеральні індивіди цього етапу характеризуються крупними гармошко-, червоподібними мінеральними агрегатами, що утворюються по периферії уламкових зерен плагіоклазу, гідрослюди, кварцу або виникають з речовини міжзернового простору (рис. 2, а, к, л).

У досліджуваних породах відмічено і перерозподіл кремнезему. Епігенетичний кварц регенерує уламкові зерна. У піщаних різновидах порід формації розвинутий аутигенний кварц, що виповнює поровий простір та заміщує інші мінерали, насамперед ілітові та каолінітові тонколускуваті агрегати, що утворюються при зміні польових шпатів та слюд (рис. 2, а-г). Кварц кристалізується у вигляді правильних кристалів, які у шліфах можуть бути окремими кристалами або утворювати мозаїчно-бластичні агрегати з лапчастими або рівними краями. В таких агрегатах присутній домішок дрібних зерен кварцу, польових шпатів, гідрослюд, гідрогематиту (рис. рис. 2, в).

Одним з останніх етапів епігенетичних перетворень порід формації була карбонатизація. Закономірності її поширення потребують ще детального вивчення. Проаналізований матеріал дозволяє встановити породи, в яких карбонатизація проявляється спорадично, як, наприклад, у алевритопісковиках (рис. 1, зр 1), та породи, в яких карбонат утворює базальний цемент, що пойкілоподібно включає уламкові зерна. Карбонати (доломіт, кальцит, анкерит) виповнюють міжзерновий простір, кородують та заміщують польові шпати, кварц, просякають глинистий цемент. Питання щодо джерел карбонатних розчинів потребують подальших досліджень, проте самі осадки могли містити достатньо карбонатів, що сприяло їх подальшій перекристалізації. 3 фрагментами органічних решток в аргілітах та алевролітах (рідше) пов'язані скупчення аутигенного діагенетичного дисульфіду заліза (переважно пірит), який утворює кристалики кубічні, інколи октаедричні та пентагонально-додекаедричні, фрамбоїди (до 0,01 мм в діаметрі) та їх скупчення (рис. 2, е). До стадії седиментогенезу відноситься і накопичення гідроксидів заліза. Розвиток у породах формації вторинних процесів та епігенетичних утворень ускладнюють встановлення та дослідження седиментаційних та діагенетичних етапів фор- 
мування порід формації. Умовно до цих етапів віднесено формування гідроксислів заліза та дисульфідів заліза, зокрема піриту. Встановлення етапності та інтенсивності постдіагенетичного перетворення порід сприятиме детальній кореляції розрізів досліджуваної формації, оцінці колекторських властивостей порід та інших практичних питань нафтової геології.

Як показали дослідження із застосуванням скануючого мікроскопа JEOL-6490 LV з енергодисперсійною приставкою INCA Energy-450, сіро- та червоноколірні різновиди порід відрізняються тільки вмістом кальцію, сірки та кисню (тобто сульфату кальцію), а забарвлення визначається мінеральною формою знаходження заліза та співвідношенням між залізом (II) і залізом (III). Для відкладів, що сформувалися у відновних умовах (первинні сіроколірні), характерним є переважання заліза (II) $\mathrm{FeO} / \mathrm{Fe}_{2} \mathrm{O}_{3}>1$ та значне поширення аутигенного піриту (або піротину). Окислювальне середовище формування порід відбивається у низьких значеннях $\mathrm{FeO} / \mathrm{Fe}_{2} \mathrm{O}_{3}<1(0,5)$ та присутністю новоутворень гематиту та магнетиту. Як відомо, в неметаморфізованих червоноколірних формаціях відношення $\mathrm{FeO} / \mathrm{Fe}_{2} \mathrm{O}_{3}<1$ і у породах переважає залізо (III) у вигляді оксидів та гідроксидів. Перехід гідроксидів заліза у гематит внаслідок ї дегідратації відбувається при відносно невисоких температурах на ранніх стадіях літогенезу. Сіроколірні прошарки фіксують моменти, коли в морських водах, позбавлених кисню, у придонному шарі і на дні починають переважати відновні анаеробні умови. Формування «сірих зон» відповідає періодам максимальної трансгресії і $є$ седиментаційною особливістю на відміну від сірих лінз, плям та ін., які утворюються в результаті діа- та постдіагенетичних змін.

\section{вИСНОВки}

За даними ГДС та дослідженням керну в розрізі теригенної червоноколірної (картамишської) формації на Кобзівській структурі виділено чотири ритмічно побудованих літогеофізичних товщі, які відбивають два макроритми осадконакопичення. Кореляція макроритмів (і товщ) з інших структурнофаціальних зон дозволяє припустити неповноту та наявність перерв в осадконакопиченні останніх.

Описаний нами розріз відрізняється значною потужністю, ритмічною будовою та теригенним характером - потужні прошарки карбонатних та/або сульфатних порід відсутні. Структурно-текстурні дослідження порід показали, що найхарактернішою текстурою порід $€$ горизонтальна (смугаста) шаруватість у дрібнозернистих пісковиках і алевролітах, хвиляста (з елементами косохвилястої) і лінзоподібна у алевролітах та плямиста - аргілітах (аргілітоподібних глинах). Найпоширеніший тип порід червоноколірні тонкозернисті алеврито-пісковики та аргіліти. Сіроколірні породи складають не більше 10\%. Уламкова частина порід представлена кварцом, польовими шпатами, каолінітом, ілітом (розвинувся по алюмосілікатах); цемент порід іліт-хлоритовий з гідроксидами заліза; акцесорні мінерали - циркон, монацит, апатит.

Породи формації зазнали значних катагенетичних та вторинних змін. Серед епігенетичних процесів необхідно відмітити хлоритизацію, карбонатизацію, гідрослюдизацію, каолінітизацію; спостерігаються елементи окварцювання.

Накопичення речовини формації відбувалося у мілководному басейні підвищеної солоності без ознак активного гідродинамічного режиму поблизу берегової лінії за субплатформених умов в арідному кліматі, областю живлення якого була пенепленізована рівнина.

1. Айзенверг Д.Е, Берченко О.И., Бражникова Н.Е. и др. Геология и нефтегазоносность Днепровско-Донецкой впадины. Стратиграфия. - Киев: Наук. думка, 1988. $148 \mathrm{c}$.

2. Берченко О.И., Боярина Н.И., Вакарчук Г.И. и др.Геологическая история территории Украины. Палеозой. - Киев: Наук. думка, 1993. - 199 с.
3. Карпова Г.В. Глинистые минералы и их эволюция в терригенных отложениях. - Недра, Москва, 1972. - 174 с.

4. Нестеренко Л.П. Нижнепермские отложения Кальмиус-Торецкой котловины Донецкого бассейна (Опыт изучения по лутугинской методике). - Высшая школа, Киев-Донецк, 1978. -148 с.

5. Стратиграфія УРСР. - Киев: Наук. думка, 1970. - 199 с.

\footnotetext{
${ }^{1}$ Institute of Geological Sciences NAS Ukraine, Kyiv, Ukraine

1 Інститут геологічних наук НАН України, м. Київ, Україна

2 Scientific Research Institute of Oil and Gas Industry of National Joint-Stok Company "NAFTOGAZ OF UKRAINE"

2 НАК «Нафтогаз України» Дочірнє підприємство «Науково-дослідний інститут нафтогазової промисловості»
} 
До статті С.Б. Шехунова, О.А. Шевченко, С.О. Мачулина...

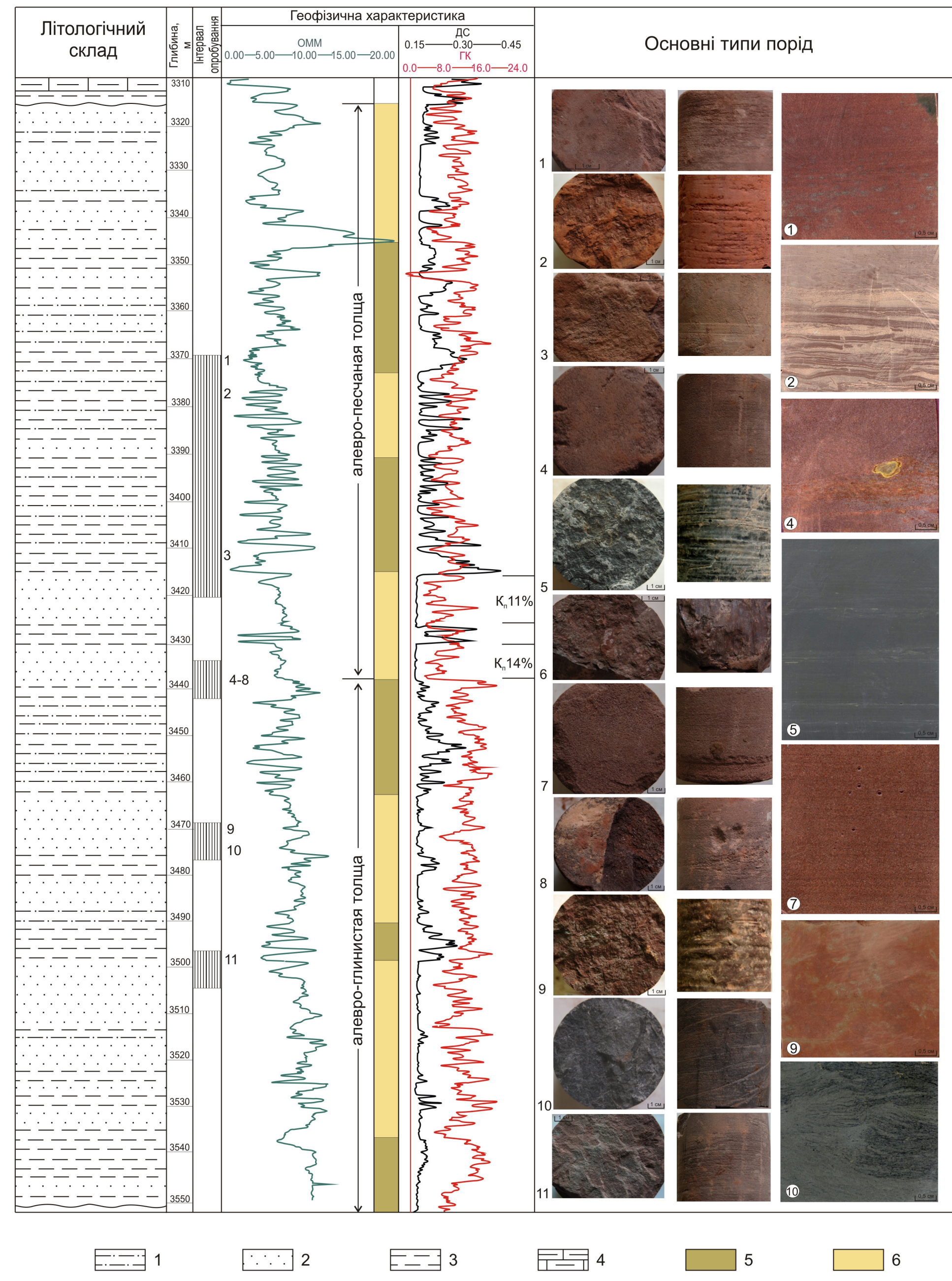

Рис. 1. Зведений розріз нижньопермської теригено-червонокольорної (картамишської) формації дД3 (Кобзівска площа).

Умовні позначення: 1 - алевроліт, 2 - піщанник, 3 - аргіліт, 4 - глинистий вапняк, 5 - переважно глинисті утворення, 6 - переважно піщанисті утворення. 